\title{
FTA and Innovation Systems
}

\section{Andersen, Per Dannemand; Johnston, Ron; Saritas, Ozcan}

\section{Published in:}

Technological Forecasting and Social Change

Link to article, DOI:

10.1016/j.techfore.2016.12.012

Publication date:

2017

Document Version

Peer reviewed version

Link back to DTU Orbit

Citation (APA):

Andersen, P. D., Johnston, R., \& Saritas, O. (2017). FTA and Innovation Systems. Technological Forecasting and Social Change, 115, 236-239. https://doi.org/10.1016/j.techfore.2016.12.012

\section{General rights}

Copyright and moral rights for the publications made accessible in the public portal are retained by the authors and/or other copyright owners and it is a condition of accessing publications that users recognise and abide by the legal requirements associated with these rights.

- Users may download and print one copy of any publication from the public portal for the purpose of private study or research.

- You may not further distribute the material or use it for any profit-making activity or commercial gain

- You may freely distribute the URL identifying the publication in the public portal

If you believe that this document breaches copyright please contact us providing details, and we will remove access to the work immediately and investigate your claim 


\title{
FTA and Innovation Systems
}

\author{
Per Dannemand Andersen*, Ron Johnston, Ozcan Saritas
}

*) Corresponding author, pean@dtu.dk

Keywords: FTA, Foresight, Innovation Systems, Innovation Policy, Review

\section{Introduction}

This special issue is one of the outputs of the $5^{\text {th }}$ International Conference on Future-Oriented Technology Analysis held in Brussels 27-28 November 2014. The articles in the special issue were selected from the manuscripts presented at the conference considering their relevance for Foresight and Innovation Systems. A few additional articles have been accepted through an open 'call for papers' process for this special issue.

The meaning and definition of the terms, "Future-oriented Technology Analysis (FTA)" and Foresight is debated in the literature (Sardar 2010; Oner 2010). To facilitate a dialogue between different epistemic communities the Joint Research Centre Institute for Prospective Technological Studies (JRC-IPTS) of the European Commission has introduced the label Future-oriented Technology Analysis (FTA) as a common umbrella term for technology foresight, technology forecasting and technology assessment. For the contributions to this special issue, we have narrowed in the meaning of FTA to cover Foresight in relation to public policy within science, technology and innovation. The term Foresight was introduced in 1984 in the book 'Foresight in Science. Picking the Winners' (Irvine \& Martin 1984). According to Martin (2010), the term foresight was used in this book as a convenient expression for a variety of techniques, mechanisms and procedures designed to identify areas of basic research with the potential to develop strategic potential. Hence, the relation to public policy was clear. As no commonly agreed terminology exists, the editors of this special issue have left it to the authors of each article to select their own. Hence, the articles use the terms Foresight, Future-Oriented Technology Analysis (FTA), and Forward-Looking Activities (FLA). Further definitions and distinctions may also be found in each article of the special issue.

In 1999, Ben Martin and Ron Johnston in this journal published the paper, 'Technology Foresight for Wiring Up the National Innovation System' (Martin \& Johnston 1999). The article emphasises the role and function that Foresight could play in enhancing the performance of innovation systems. Based on case studies of Foresight activities in three English-speaking countries, the article linked these experiences with the wide literature on technology and innovation policy. The conclusion was that technology foresight has a potentially important role to play in relation to national innovation systems, strengthening them in terms of the capacity to learn and innovate. In the period since 1984 and 1999 the practice and the theoretical understanding of foresight for innovation policy have undergone significant changes. This development have been described and discussed in several studies (Georghiou 2001; Tegart \& Johnston 2004; Miles 2008; Miles 2010; Andersen \& Alkærsig 2016). This development mirrors the development in the wider field of innovation studies and innovation policy in the same period (Fagerberg \& Verspagen 2009; Martin 2014). Martin and Johnston's article took its theoretical departure from the much larger and wider literature on technology and innovation policy. This literature has also developed significantly since 1999, and there is still a huge potential for foresight to draw from and contribute to the larger literature on innovation studies, industrial dynamics, and technology and innovation policy. The academic field of innovation studies has gradually expanded since the 1960 s to include several thousand contributors from 
all over the world (Fagerberg \& Verspagen 2009). Although with strong roots in the 1950s, the academic field of foresight for innovation policy has mainly developed since the 1980s and includes probably only hundreds -- if not less -- of contributors, of which many are practitioners more than scholars ${ }^{1}$.

A recent review of the two academic fields of innovation studies and foresight, respectively, showed that the two fields have co-evolved over the years (Andersen \& Andersen 2014). The review also argued that the field of foresight over the years has imported academic insight on innovation from the field of innovation studies, and that the field of foresight has been in a perpetual catching-up process vis-à-vis the field of innovation studies.

The conceptual interconnection between foresight and wider innovation literature has been explored by several studies (Alkemade et al. 2007; Cagnin et al. 2012). However, these studies often focus on how foresight can contribute to innovation system policies, with foresight being regarded as one among a range of other systemic policy instruments (Smits et al. 2010). As the field of foresight is in a catching-up process in relation to the field of innovation studies, it is relevant to study how the recent development in the innovation literature can contribute to the practice and to the theoretical underpinning of foresight.

Jan Fagerberg, Ben Martin and colleagues have in several recent articles summarised the field of innovation studies - including innovation policy studies - and its development (Fagerberg \& Verspagen 2009; Fagerberg et al. 2012; Fagerberg 2016; Martin 2012; Martin 2014). One of the most important developments described in these studies is that innovation system studies increasingly have adopted a more systemic and evolutionary understanding of innovation. Foresight for innovation policy has responded to this development by also including a more systemic and evolutionary understanding of innovation into its conceptual development and its applied practice (Alkemade et al. 2007; Abadie et al. 2010; Saritas 2011; Cagnin et al. 2012; Andersen \& Andersen 2014; Andersen \& Alkærsig 2016). Hence, the special interest in this special issue on foresight and innovation systems.

\section{Recent developments in foresight and innovation systems}

In the following, we will elucidate three recent developments in foresight and innovation system studies and link each of these trends to this special issue. First, the wider field of innovation policy studies has recently noted that policy making has changed its focus on the national level to a more complicated situation with policy intervention on multiple levels: supra-national, national and regional (Martin 2014). Also foresight has broadened its interest in policies for national innovation systems to comprise related concepts such as sectoral innovation systems (Abadie et al. 2010; Andersen et al. 2014), innovation systems around emerging developments in technology (e.g. Hekkert et al. 2010), regional innovation systems and clusters (Roveda \& Vecchiato 2008; Vecchiato \& Roveda 2014; Keller et al. 2015). The interest in foresight and regional innovation systems is not new (Cooke et al. 1997; Gavigan et al. 2001; Asheim \& Gertler 2005), but has received increasing attention in recent years, both from the wider regional innovation system community (Boschma \& Frenken 2011; Markard et al. 2009) and from policy-making. However, regional foresight exercises are often criticised for producing standard recommendations that disregard the regional context. What is required is an understanding of the regional context and inclusion of regional business

\footnotetext{
${ }^{1}$ A simple search in Scopus on the terms 'foresight' and 'innovation' in 'Article Title, Abstract, Keyword' resulted in 660 publications, and that only 53 authors have published more than 2 articles (26 October 2016).
} 
communities, institutions and governmental agencies (Foray et al. 2011). Most recently smart specialisation (RIS3) has become an important policy concept under the Europe 2020 agenda (Foray et al. 2011; Foray 2014). Foresight's role vis-à-vis regional innovation policies and the smart specialization agenda is of particular interest to less advanced and transition regions of Europe (Paliokaite et al. 2015).

Four articles in the special issues relate to this second overall development in foresight and innovation policy studies.

Weber and Schaper-Rinkel (Weber \& Schaper-Rinkel 2017) take their theoretical departure from Franco Malerba's work on sectoral innovation systems (Malerba 2002). Empirically, they draw on insights from and across - nine sectoral foresight reports carried out as Sectoral Innovation Watch projects within the Europe INNOVA initiative launched by the European Commission's Directorate General Enterprise and Industry. Their contribution to this special issue has two purposes. First, to outline the conceptual and methodological features of what they define as the Sectoral Innovation Foresight. Second, to illustrate the benefits of a systematic multi-sector foresight by extracting some cross-cutting insights generated across the nine analysed sectors.

Haddad and Maldonado (Haddad \& Uriona Maldonado 2017) also focus on sectoral innovation systems. They take their main theoretical departure in the framework of technological innovation systems (TIS) and that framework's functions of innovation systems (Hekkert et al. 2007; Alkemade et al. 2007), and combine this perspective with the literature on technology roadmaps (Phaal et al. 2004). The contribution presents a case study of a sectoral roadmap exercise aiming at establishing an automotive sector in the Santa Catarina State of Brazil. Among their key findings are some recommendations for the design of technology roadmap exercises. The 'functions approach' can improve the identification of key actors, technologies and institutional setup and improve the understanding of the dynamic character of the sector in question.

Featherston and O'Sullivan (Featherston \& O'Sullivan 2017) have reviewed over 240 international FTArelated policy documents for the sector of advanced materials. As such, this contribution focuses on a generic technology rather than on an industrial sector or a geographical entity. This paper explores ways that FTA might be structured for more detailed investigation of the complex innovation system journeys of new generic technologies, as they are developed, diffused, and deployed. The paper proposes three structural elements to characterise innovation systems and their dynamics: 1) 'infratechnologies' required to develop emerging technologies, 2) key phases of emergence lifecycles and 3) key stages of industrial value chains. The article argues that such an insight is useful for identifying and manage technology R\&D portfolios, prioritise investments and coordinate among public innovation agencies.

Pombo-Juárez et al. (Pombo-Juárez et al. 2017) depart from Martin and Johnston's (1999) notion of foresight potential as an instrument for wiring up innovation systems and take a multi-level perspective to foresight and innovation systems. The article argues that innovation is subject to framework conditions not only within, but also across, multiple layers of innovation systems. This includes local, regional, national and international levels of such systems. A key finding in the article is that systemic interconnections and interactions within and across different innovation systems should be reflected both in the design and in implementation of foresight exercises as well in recommendations resulting from foresight exercises. 
Piirainen, Tanner and Alkærsig (Piirainen et al. 2017) take a smart specialisation approach to an emerging sector: the offshore wind servicing sector. The article explores the typology of structural change pattern of a region, which is a core feature in the smart specialisation framework (Foray 2014). Among the article's key contributions to the practice and scholarly field of foresight is that the suggested typology of smart specialisation dynamics provides an analytic framework for regional development, and that this framework enables a comprehensive anticipation of the industrial dynamics in the sector. Furthermore, such a typology can be used to identify plausible development paths based on actual regional capabilities.

Ho and O'Sullivan (Ho \& O'Sullivan 2017) in this issue discuss the topic of standardisation for innovation activities. A roadmapping procedure is introduced to enable standardisation for making the innovation process more efficient. The discussion is carried out around the Information and Communication Technologies (ICTs) domain, and smart systems in particular, where a number of hi-tech devices and applications need to interact with each other to achieve interoperability. Future-oriented technology analysis (FTA) is considered to play a role for the anticipation and management of standards. The paper proposes a systematic and structured process for managing roadmapping, as a commonly used technique in FTA studies, to support effective standardisation processes in a highly complex and heterogeneous area of smart systems. Proposals are made on how roadmaps can be better structured and managed for effectively addressing standardisation issues.

Second, there is an increased request for impact assessment of foresight as a tool in innovation policies and its impact in general (Georghiou \& Keenan 2006; Havas et al. 2010; Harper 2013). Also the wider innovation policy literature has stressed the need for evidence-based policy making (Martin 2014). Three articles in this special issue relate to this development in foresight and innovation policy studies.

One focus of innovation policy is collaboration, which is seen as a key to unlocking productivity improvements, both as an integral process of the knowledge economy and to produce economy of scale and learning-based cost reductions. But translation of this objective into regular accepted practice faces many challenges. Forward looking activities (FLAs previously labelled foresight) have been proposed as a process that could assist in addressing these challenges.

Haegeman, Spiesburger and Könnölä (Haegeman et al. 2017) examine this issue in the context of transnational research programming. They demonstrate the value of an evaluation scheme which assesses relevance, efficiency, effectiveness and utility/appropriateness /sustainability to a program to develop shared research programs between the EU and Russia.

Havas and Weber (Havas \& Weber 2017) start from the perspective that FLAs have been available to science, technology and innovation policies for several decades, but that knowledge of impact is markedly limited. They seek to address this deficit by analysing the fit between different types of FLAs and 'innovation policy governance sub-systems' which contribute to identifying and prioritising policy needs and problems; the better the fit, the greater the likely impact. Based on detailed case studies of FLAs in Germany, Greece and Hungary, they conclude there is a need for a far closer tailoring of FLA design to the characteristics of the relevant component of the innovation system.

Couto e Silva, Silberglitt, Machado, Maia and Cagnin (do Couto e Silva et al. 2017) describe a new approach to directing foresight towards weaknesses in the national innovation system. They combined foresight, national innovation indices (based on the Global Innovation Index data) and decision analysis to 
identify the best combination of investments to improve a national innovation system, using Brazil as an example. Applications include informing policy-makers of possible gaps in innovation strategies and shaping foresight studies to contribute more directly to improving a country's innovation performance.

Third, the availability of 'big data' has created new methodological opportunities in innovation studies. A recent special issue of Research Policy discussed the potential of this new frontier in innovation studies (Feldman et al. 2015). Scholars of innovation studies have for long use quantitative and statistical data such as patent databases and bibliometrics as well as statistical data from national authorities and from OECD and EuroStat. New technological possibilities such as machine learning and large data capacity open up possibilities for large-scale data linkages, text mining, and data of behaviour at the level of the individual. Such new possibilities have for quite some time also been examined in the field of foresight. A recent book has identified some of the promising opportunities of such large data analyses (Daim et al. 2016). Two articles in this special issue relate to the use of quantitative approaches in foresight and innovation policy studies. One article by, Piirainen, Tanner and Alkærsig, is already mentioned above.

The other article, by Kayser (Kayser 2017) in this issue argues that when analysing innovation systems it is important to consider additional considerations reaching beyond the scientific discourse. Further outreach to the public discourse is proposed as a key indicator for diffusion of innovations. A text mining framework is used to analyse scientific discourse through scientific publications, and public discourse through news articles. The results of analyses are then compared through a process model, which is described in detail. The methodology is demonstrated through three case studies on cloud computing, artificial photosynthesis and vegan diet. The comparison of information sources from science and media provide valuable insights about the level and extent of innovation diffusion and matches and mis-matches on how certain innovations are perceived by scientists and the society.

\section{Acknowledgement}

The editors of this special issue are indebted to discussions with and contributions from members of steering committee of the $5^{\text {th }}$ International Conference on Future-Oriented Technology Analysis held in Brussels 27-28 November 2014. In particular, we are indebted to Luke Georghiou, Karel Haegeman, Jennifer Cassingena Harper, Fabiana Scapolo and Matthias Weber. Furthermore, we are grateful to all the anonymous reviewers who carefully have reviewed the submitted manuscripts. Finally, we would like to wish all the best for the further development of the manuscripts that were not accepted for this special issue. Contributions to this work by Ozcan Saritas were provided within the framework of the Basic Research Program at the National Research University HSE and were supported within the framework of the subsidy granted to the HSE by the Government of the Russian Federation for the implementation of the Global Competitiveness Program.

\section{References}

Abadie, F., Friedewald, M. \& Weber, K.M., 2010. Adaptive foresight in the creative content industries: anticipating value chain transformations and ned for policy action. Science and Public Policy, 37(1), pp.19-30.

Alkemade, F., Kleinschmidt, C. \& Hekkert, M., 2007. Analysing emerging innovation systems: a functions approach to foresight. International Journal of Foresight and Innovation Policy, 3(2), pp.139-168. 
Andersen, A.D. \& Andersen, P.D., 2014. Innovation system foresight. Technological Forecasting and Social Change, 88, pp.276-286. Available at: http://linkinghub.elsevier.com/retrieve/pii/S0040162514002169 [Accessed September 11, 2014].

Andersen, P.D. et al., 2014. Sectoral innovation system foresight in practice: Nordic facilities management foresight. Futures, 61, pp.33-44. Available at: http://linkinghub.elsevier.com/retrieve/pii/S0016328714000743 [Accessed August 1, 2014].

Andersen, P.D. \& Alkærsig, L., 2016. Profile and trends of FTA and Foresight. In T. U. Daim et al., eds. Anticipating Future Innovation Pathways through Large Data Analytics. Springer Berlin Heidelberg.

Asheim, B.T. \& Gertler, M., 2005. The geography of innovation: regional innovation systems. In J. Fagerberg, D. Mowery, \& R. Nelson., eds. The Oxford handbook of innovation. Oxford University Press, USA.

Boschma, R. \& Frenken, K., 2011. Technological relatedness and regional branching. In H. Bathelt, M. P. Feldman, \& D. F. Kogler, eds. Beyond Territory: Dynamic Geographies of Knowledge Creation, Diffusion and Innovation. Oxon, UK: Routledge, pp. 64-81.

Cagnin, C., Amanatidou, E. \& Keenan, M., 2012. Orienting European innovation systems towards grand challenges and the roles that FTA can play. Science and Public Policy, 39(2), pp.140-152.

Cooke, P., Uranga, M.G. \& Etxebarria, G., 1997. Regional innovation systems: Institutional and organisational dimensions. Research policy, 26, pp.475-491.

do Couto e Silva, E. et al., 2017. A portfolio analysis methodology to inform innovation policy and foresight. Technological Forecasting and Social Change, (This issue). Available at: http://dx.doi.org/10.1016/j.techfore.2016.06.032.

Daim, T.U. et al. eds., 2016. Anticipating Future Innovation Pathways Through Large Data Analysis, Springer. Available at: http://link.springer.com/10.1007/978-3-319-39056-7.

Fagerberg, J., 2016. Innovation Policy: Rationales, Lessons and Challenges. Journal of Economic Surveys, 0(0), pp.1-16. Available at: http://doi.wiley.com/10.1111/joes.12164.

Fagerberg, J., Fosaas, M. \& Sapprasert, K., 2012. Innovation: Exploring the knowledge base. Research Policy, 41(7), pp.1132-1153. Available at: http://linkinghub.elsevier.com/retrieve/pii/S0048733312000698 [Accessed July 9, 2014].

Fagerberg, J. \& Verspagen, B., 2009. Innovation studies-The emerging structure of a new scientific field. Research Policy, 38(2), pp.218-233. Available at: http://linkinghub.elsevier.com/retrieve/pii/S0048733308003016 [Accessed July 20, 2011].

Featherston, C.R. \& O'Sullivan, E., 2017. Enabling technologies, lifecycle transitions, and industrial systems in technology foresight: Insights from advanced materials \{FTA\}. Technological Forecasting and Social Change, (This issue), p. Available at:

http://www.sciencedirect.com/science/article/pii/S0040162516301342.

Feldman, M., Kenney, M. \& Lissoni, F., 2015. The New Data Frontier: Special issue of Research Policy. Research Policy, 44(9), pp.1629-1632. Available at: http://dx.doi.org/10.1016/j.respol.2015.02.007.

Foray, D., 2014. From smart specialisation to smart specialisation policy. European Journal of Innovation Management, 17(4), pp.492-507.

Foray, D., David, P.A. \& Hall, B.H., 2011. Smart specialization From academic idea to political instrument, the surprising career of a concept and the difficulties involved in its implementation, Lausanne. Available at: http://infoscience.epfl.ch/record/170252/files/MTEI-WP-2011-001Foray_David_Hall.pdf.

Gavigan, J.P. et al., 2001. A Practical Guide to Regional Foresight, Available at: foresight.jrc.ec.europa.eu/documents/eur20128en.pdf. 
Georghiou, L., 2001. Third Generation Foresight - Integrating the Socio-economic Dimension. NISTEP Study Material.

Georghiou, L. \& Keenan, M., 2006. Evaluation of national foresight activities: Assessing rationale, process and impact. Technological Forecasting and Social Change, 73(7), pp.761-777. Available at: http://linkinghub.elsevier.com/retrieve/pii/S004016250500137X [Accessed November 9, 2012].

Haddad, C.R. \& Uriona Maldonado, M., 2017. A functions approach to improve sectoral technology roadmaps. Technological Forecasting and Social Change, (This issue). Available at: http://dx.doi.org/10.1016/j.techfore.2016.08.006.

Haegeman, K., Spiesberger, M. \& Könnölä, T., 2017. Evaluating foresight in transnational research programming. Technological Forecasting and Social Change, (This issue). Available at: http://dx.doi.org/10.1016/j.techfore.2016.07.017.

Harper, J.C., 2013. Impact of technology foresight. Nesta Working Paper, 13/16(13). Available at: http://www.nesta.org.uk/publications/impact-technology-foresight.

Havas, A., Schartinger, D. \& Weber, M., 2010. The impact of foresight on innovation policy-making: recent experiences and future perspectives. Research Evaluation, 19(2), pp.91-104. Available at: http://openurl.ingenta.com/content/xref?genre=article\&issn=09582029\&volume $=19 \&$ issue $=2 \&$ spage $=91$ [Accessed February 3, 2012].

Havas, A. \& Weber, K.M., 2017. The "fit" between forward-looking activities and the innovation policy governance sub-system: A framework to explore potential impacts. Technological Forecasting and Social Change, (This issue). Available at: http://dx.doi.org/10.1016/j.techfore.2016.07.016.

Hekkert, M.P. et al., 2007. Functions of innovation systems: A new approach for analysing technological change. Technological Forecasting and Social Change, 74(4), pp.413-432.

Ho, J.Y. \& O'Sullivan, E., 2017. Strategic standardisation of smart systems: A roadmapping process in support of innovation. Technological Forecasting and Social Change, (This issue). Available at: http://dx.doi.org/10.1016/j.techfore.2016.04.014.

Irvine, J. \& Martin, B.R., 1984. Foresight in Science: Picking the Winners, London: Pinter Publishers.

Kayser, V., 2017. Comparing public and scientific discourse in the context of innovation systems. Technological Forecasting and Social Change, (This issue). Available at: http://dx.doi.org/10.1016/j.techfore.2016.08.005.

Keller, J., Markmann, C. \& von der Gracht, H.A., 2015. Foresight support systems to facilitate regional innovations: A conceptualization case for a German logistics cluster. Technological Forecasting and Social Change, 97, pp.15-28. Available at: http://dx.doi.org/10.1016/j.techfore.2013.12.031.

Malerba, F., 2002. Sectoral systems of innovation and production. Research Policy, 31(2), pp.247-264.

Markard, J., Stadelmann, M. \& Truffer, B., 2009. Prospective analysis of technological innovation systems: Identifying technological and organizational development options for biogas in Switzerland. Research Policy, 38(4), pp.655-667. Available at: http://linkinghub.elsevier.com/retrieve/pii/S0048733309000183 [Accessed May 19, 2015].

Martin, B.R., 2014. $R$ \& D Policy Instruments - a Critical Review of What We Do and Don ' $t$ Know, Aalborg.

Martin, B.R., 2012. The evolution of science policy and innovation studies. Research Policy, 41(7), pp.12191239.

Martin, B.R. \& Johnston, R., 1999. Technology foresight for wiring up the national innovation system: experiences in Britain, Australia, and New Zealand. Technological Forecasting and Social Change, 60(1), pp.37-54. 
Miles, I., 2008. From Futures to Foresight. In The Handbook Of Technology Foresight: Concepts and Practice.

Miles, I., 2010. The development of technology foresight: A review. Technological Forecasting and Social Change, 77(9), pp.1448-1456. Available at: http://linkinghub.elsevier.com/retrieve/pii/S0040162510001794 [Accessed November 7, 2012].

Oner, M.A., 2010. On theory building in Foresight and Futures Studies: A discussion note. Futures, 42(9), pp.1019-1030.

Paliokaite, A., Martinaitis, Ž. \& Reimeris, R., 2015. Foresight methods for smart specialisation strategy development in Lithuania. Technological Forecasting and Social Change, 101, pp.185-199.

Phaal, R., Farrukh, C.J.P. \& Probert, D.R., 2004. Technology roadmapping - A planning framework for evolution and revolution. Technological Forecasting and Social Change, 71(1), pp.5-26.

Piirainen, K.A., Tanner, A.N. \& Alkærsig, L., 2017. Regional foresight and dynamics of smart specialization: A typology of regional diversification patterns. Technological Forecasting and Social Change, (This issue). Available at: http://dx.doi.org/10.1016/j.techfore.2016.06.027.

Pombo-Juárez, L. et al., 2017. Wiring up multiple layers of innovation ecosystems: Contemplations from Personal Health Systems Foresight. Technological Forecasting and Social Change, (This issue).

Roveda, C. \& Vecchiato, R., 2008. Foresight and innovation in the context of industrial clusters: The case of some Italian districts. Technological Forecasting and Social Change, 75(6), pp.817-833. Available at: http://linkinghub.elsevier.com/retrieve/pii/S0040162508000425 [Accessed November 7, 2012].

Sardar, Z., 2010. The Namesake: Futures; futures studies; futurology; futuristic; foresight-What's in a name? 光. Futures, 42(3), pp.177-184. Available at: http://linkinghub.elsevier.com/retrieve/pii/S001632870900175X [Accessed February 20, 2012].

Saritas, O., 2011. Systemic foresight methodology. In Forth International Seville Conference on FutureOriented Technology Analysis (FTA) FTA and Grand Societal Challenges - Shaping and Driving Structural and Systemic Transformations SEVILLE, 12-13 MAY 2011.

Smits, R. et al., 2010. The Role of Technology Assessment in Systemic Innovation Policy. In R. E. Smits, S. Kuhlmann, \& P. Shapira, eds. The Theory and Practice of Innovation Policy: An International Research Handbook.

Tegart, G. \& Johnston, R., 2004. Some Advances in the Practice of Foresight. In EU-US Seminar: new technology foresight, forecasting and assesment methods. Seville, Spain, pp. 30-46.

Vecchiato, R. \& Roveda, C., 2014. Foresight for public procurement and regional innovation policy: The case of Lombardy. Research Policy, 43(2), pp.438-450. Available at: http://dx.doi.org/10.1016/j.respol.2013.11.003.

Weber, K.M. \& Schaper-Rinkel, P., 2017. European sectoral innovation foresight: Identifying emerging cross-sectoral patterns and policy issues. Technological Forecasting and Social Change, (This issue), pp.1-11. Available at: http://dx.doi.org/10.1016/j.techfore.2016.09.007. 